\title{
The Development Process and Future Prospects of Auctions
}

\author{
Yibing Jiang ${ }^{1 *}$ \\ ${ }^{1}$ Beijing 101 High School International Department, Beijing, China \\ ${ }^{*}$ Corresponding author.Email: guanghua.ren@gecacdemy.cn
}

\begin{abstract}
The article focuses on the development process of the different types of auctions. Later the paper further discussed two types of auction: Dutch auction and English auction, and then compared the differences between Dutch auction and English auction to help people better apply these two types in reality. Based on this information, the article predicted the prospects of the auction. Thereby, people can prepare for future auctions sooner. This paper mainly uses the literature to review the development and features of auctions and claims that the live auctions will be moved online in the future due to the spread of the internet and Covid 19. Moreover, the revenue equivalence theorem is also reviewed to better understand the auction in general. Thus, people should create more auction websites to cope with the huge demand in the future, and people should adapt to the online forms as soon as possible.
\end{abstract}

Keywords: Dutch auction, English auction, future prospects, development process, online auction.

\section{INTRODUCTION}

Auctions offer a special way to sell items based on bidders competing against each other to win the bid. The seller tries to make the most money or finish the auction in the shortest time from the sale, while bidders try to purchase an item for the desired evaluation. A seller can offer almost anything at an auction: from invaluable paintings to domestic items. The competing bidders, rather than the sellers, set the prices for these items [1]. The origin of auctions can be traced back to approximately 500 B.C. in ancient Greece, when women were sold for marriage. This kind of auction followed a descending pricing method, beginning with a high price and going lower until the lowest bid was found, as long the bid price was more than, or equal to, the reserve price set by the seller [2]. With its development, today there are more than 5 kinds of auctions: English auction, Dutch auction, first pricesealed bid auction, silent auction, etc. All these auctions have their own features, so they will be applied to different situations. However, sometimes people may utilize an unsuitable type of auction, which is opposite to the actual situation and will cause the loss of profits. For example, scientists searched for buyer and seller behaviors in fish markets organized as Dutch auctions from a wholesale fish market in Southern Europe. They found that Dutch auction increases competition between sellers but not between buyers. Therefore, Dutch auctions may not be suitable for fishermen to extract the maximum revenue from buyers [3]. People have insufficient understanding and improper use of the essential characteristics of different auction methods, resulting in excessively high costs.

Therefore, it is critical to use a correct and suitable auction. To be more focused, this paper will concentrate on English auctions and Dutch auctions to investigate their differences and similarities. By comparing and analyzing the characteristics of the two auction methods, people can gain a basis for choosing a suitable auction method in different application scenarios to maximize the benefits.

Recently, as the internet spreads fast and with the spurt of the Covid 19, the auction changes again. Many people begin to organize auctions online. In China, people who sign up for the applications can auction some used stuffs. Thus, if the world changes so fast, what will the auction be like in the future? Can people predict the foreground of the auction? Many scientists predict that the auctions will be definitely held online more often. According to Emlyn Scott, as auctions move to the worldwide online forum, they can gain more audiences, so the future of auctions will be influenced and transfer online. Emlyn Scott mentions that as more people use the internet because the internet 
can make people connect to each other, more people will have the chance to take part in online auctions. Then, there will be a fiercer bidding competition [4]. Rodney McConnel says that online auctions mainly break and eliminate the physical restriction of on-site auctions like geography, existence, time, space, and smaller target audiences [5]. With the help of technology, auctions have evolved from live auctions to online auctions.

Hence, people need to clearly understand the development of the auction, the features of different kinds of auctions, and the current type of auctions. In this way, the human can postulate what the auction will be like in the future. Therefore, this paper will solve the question of whether people can predict the prospect of the auction. The article will review the auction's development and the auction's features, then compare the Dutch auction and English auction. Finally, the article will predict the future of the auction and give some suggestions for related people.

\section{MAIN BODY}

\subsection{The Auction in Macro Understanding}

\subsubsection{The Features of The Auction}

From early on, there is a multitude of ways to sell goods. People can open a small shop to sell some life necessities. On the other hand, people can buy luxury products in the store. Anyway, there are so many methods to sell and buy goods, so why do people use the auction? Actually, the auction provides people with a way to contact the rare products that you cannot see in the normal store. By using the auction, the sellers can auction their goods at a higher price, and buyers can get a chance to buy the things they want.

To set up an auction, the auctioned item should not have a fixed or determinable market value, or the seller is uncertain about the market price [6]. When the price of a certain good is a consensus, everyone's evaluation will equal, and no one will be willing to bid up.

\subsubsection{The Development of The Auction}

The earliest record of auction can be traced back to 500BC in ancient Greece. At that time, women could be sold by their families as the bride. A similar thing happened in Roman. At first, auctions in Roman, called "atrium actinium", were mainly about selling estate goods and property. Later, people organized auctions to regularly sell the spoils of war, slaves, and debtors' assets.

However, after the collapse of the Roman empire, the popularity of the auction decreases a lot. Until the 17 th century, the rise of the candle auction rekindled people's passion for the auction. In a candle auction, people would consistently bid up until the candle burnt out. In this way, people couldn't know the product's final price until the last moment, which added some curiosity and a sense of anticipation to the auction. Since then, the auction became more and more popular, and the auction houses proliferated [7].

Then, as the demand for auctions increased, many different types of auctions began to rise. In the early 1600 s, the tulips were suddenly introduced into Holland by traders from the Ottoman empire, which aroused the curiosity of local people. Since the tulips were so unique that people had never seen such flowers before, many people wanted to own this kind of flower, causing the demand to surge in a short time. Akin to the imagination, like people today suddenly see a bright pink cat. However, as the demand increased quickly, the supply was more stable because tulips had an extremely long production cycle. Furthermore, tulips couldn't last for a long time during the trade: they could only be traded in 3 months. The result was the first modern futures contract: at any time during the year, tulip sellers and buyers would sign a contract to deliver $\mathrm{X}$ amounts of tulips on a certain date in Summer at price Y. Thus, the futures market in the modern day is a direct consequence of the Dutch traders who wanted to trade tulips year-round despite being botanically checked to physically trade them and delivering them for only 3 months each year [8]. Therefore, the Dutch auction appeared to connect sellers and buyers to trade tulips.

Almost at the same time, there were some auctions of art in England regularly appearing in the bars, coffee houses, and taverns. These auctions foreshadowed the later auctions with larger artworks. In these art auctions, the price will be ascending so that, at last, one person could get the item [2].

In recent years, as the internet spreads worldwide, more and more auctions have begun to be held online. According to the European Fine Art Foundation, the online art auction industry accounted for 2.8 billion of sales in 2014 [9]. Besides, there are many auction websites now. For instance, Goodwill is a nonprofit organization that operates retail stores to raise money for poor or disable people. Shop Goodwill, its bidding website, provides various unique products (Art, Tools, Clothing, Musical Instruments), and it is a really easyto-use platform.

\subsection{Auction Theory}

\subsubsection{Dutch Auction Theory}

In a Dutch auction, the sellers will initially set up a very high price and lower the price until a bidder stops the auction and claims the object for that price. According to Vickrey, the decision faced by a bidder 
with a certain valuation is essentially static, i.e., the bidder has to choose the price level at which he will claim the object if it has not yet been claimed. The winner will be the one who chooses the highest level, and the price he pays will be equal to that amount [10].

\subsubsection{English Auction Theory}

In an English auction, the auctioneer starts bidding at a low price (a price below which the item will not be sold). Then, bidders increase the price, and the followers will decrease, and finally, there is only one person who is willing to bid. In an auction with multiple items, the auction will continue until the supply of the items matches the demand for the items. In this case, the bidder's strategy must specify whether he will be active at any given price level for each of his possible valuations based on his previous activity observed during the auction process. Nevertheless, suppose the bidder knows the value of the certain object to himself. In that case, he will have a straightforward advantageous strategy- actively bidding until the price reaches the valuation value. Regardless of the strategy adopted by other bidders, this simple strategy will be the best answer [10].

\subsection{Revenue Equivalence Theorem}

The Revenue Equivalence theorem states that under the benchmark model, all the four basic auction (English auction, Dutch auction, first sealed-bid auction, second sealed-bid auction) formats yield the same average revenue to the seller.

This theorem assumes an auction with:

1) n risk-neutral bidders [11].

2) Bidder valuations lies in real interval $[\theta 1, \theta 2]$ with $\theta 1<\theta 2$ [11].

3) Bidder valuations are drawn from $[\theta 1, \theta 2]$ with a strictly positive density $\varphi \mathrm{i}()>$.0 . Let $\varphi$ i (.) be the cumulative distribution function [11].

4) Independent bidders [11].

Now consider a given pair of Bayesian Nash Equilibrium of two different auctions procedures that satisfy:

1) For every bidder i, for each possible realization of $(\theta 1, \ldots, \theta n)$, bidder $\mathrm{i}$ has an identical probability of getting the good in the two auctions [11].

2) Every bidder $i$ has the same expected pay off in the two auctions when his valuation for the object is at its lowest possible level [11].

\subsection{The Comparison Between Dutch Auction and English Auction}

\subsubsection{The Similarity of Dutch Auction and English Auction}

According to the revenue equivalence theorem, when bidders are risk-neutral, English and Dutch auctions yield the same revenue to the sellers. However, when the situation is not risk-neutral, the revenue equivalence theorem will fail. When people are riskaverse, English auctions will generate more revenue. When it is risk-seeking, Dutch Auctions will yield more revenue.

\subsubsection{The Difference Between Dutch Auction and English Auction}

\subsubsection{The speed of the auctions}

For Dutch auction, the most evident advantage is the quickness. For specific goods, the price will start at a very high price. The bidders move a clock counterclockwise to lower the speed. As the price decreases, when one bidder stops the price and decides to buy goods at that price, he will directly speak to the seller via a microphone. Then, this turn of auction ends. Sometimes, the whole process can be finished in 4 seconds. Thus, the Dutch auction's high speed allows it to sell many highly perishable commodities like cut flowers [12]. On the other hand, for English auctions, the items are always valuable items like ancient artworks. People will increase their price until it reaches their evaluation. They won't increase too much in one round, so the time usually lasts several minutes (not long, but we have to compare it to a few seconds). Nevertheless, it doesn't mean that high speed is absolutely a good thing. Actually, a high-speed Dutch auction generates a lower revenue than the first price sealed bid [12].

\subsubsection{The strategies using in two auctions}

For English auction, there are three strategies for bidders: (a) personal valuation, (b) prior assessment of rival valuations, (c) new information obtained from the bidding process. In contrast, in a Dutch auction, the strategies are (a) personal valuation, (b) prior assessment of rival bids, and (c) no new information is obtained from the bidding process [6].

Furthermore, there will be a paradox for bidders called the "winners' curse" for English auction. It means that after successfully auctioning the item, the wined bidder will feel disappointed. Since he realizes that his evaluation of this item exceeds other people's assessments, he cannot lower the expected profit. In a study of the bidding for offshore mining rights 
auctioned by the U.S. Government, one implication of the "winner's curse" is that inexperienced bidders have lower profits than expected because when they overestimate the value of the project, these bidders are more likely to bid the highest. Bidders will feel uneasy when they find that their bids exceed 20 experts [6]!

\subsubsection{The application of English auction and Dutch auction}

Since the Dutch auction was invented to trade tulips, in the past, this type of auction was always used in the cut flower market. About $85 \%$ of Netherlands cut flowers are handled by the Dutch auctions annually [13]. Today, the Dutch auction is mainly used in business-tobusiness (B2B) settings to trade large quantities of homogeneous goods, such as commodity-like items (like cut flowers, seafood, and other perishable goods) and excess inventory [14]. Such products are not so expensive. However, actually, when valuations of auctions are affiliated, English auction can generate more revenue than Dutch auction. Thus, under the cases that the Dutch auction cannot beat against or just the same as the English auction, why use the Dutch auction to sell many non-durable goods? Researchers provide one explanation that the Dutch auction's revenue can be superior in a sequential environment that captures the essential features of the non-durable goods sale [13]. Besides, based on the Dutch auction's attributes, we can also expand its use. Researchers showed that Dutch auctions could eliminate the partnership between two participants more effectively than auctions using rising clocks.

\subsection{The Future Prediction of The Auction}

Entering the 21st century, the internet plus era has come, so many offline things in the past have changed to be held online. Many stores have been closed since people began to sell goods on the online application like Taobao or Amazon. Thus, as the internet continues to develop, the widespread internet can make online auctions really convenient. In the future, or even sometimes now, people just need a small phone to finish an auction.

Besides, since people can enact some distinct rules for certain auctions, these online auctions can satisfy more sellers and buyers. For example, Listia is an online auction website. Instead of using cash, this website offers credits for users. People can list their used items, and others can use the credits earned from selling their products to buy things they want. In this way, all processes can be finished on this website, which saves the process of transaction of cash and makes the auction quicker. Another example is an online Dutch auction called Catawiki, which burst in 2008. Catawiki also has more than 170 auctioneers who will analyze each item submitted in detail to ensure quality. By only accepting items over 75 Euros (approximately $£ 63$ ), the categories can range from classic cars to diamonds. In the future, companies can make more special rules for online auctions, which can attract many people to participate.

Actually, a more compelling reason why future auction will be held online is that online auction is more stable. During the Covid 19, people were not allowed to go outside, so many offline auctions could not come off. However, by using a website, the auction won't be influenced by such a natural disaster. People can just sit in front of a laptop and bid up.

However, when people change the form of the conventional auctions, there will be some issues accordingly. For instance, unlike the traditional English auction, which doesn't have a time limit, the English online auction often has a time interval that allows people to bid up. For example, in eBay (an online auction website), the auction will be consistent for 7 days. Under this case, many people will choose to bid up on the last day or at the last few minutes to prevent others from having time to bid up. To solve this problem, the website will add an "extension period". For example, the extension period is set to five minutes, which means that if there is a bid in the last ten minutes, the auction's closing time is automatically extended by ten minutes. This process continues until there are no bids within five minutes before the auction ends. This is only one of the online auctions, but actually, on the website, we can create many new rules to hold a successful auction, which can satisfy different standards. Thus, auctioning online is not a short term matter. Before the online auction system is mature and stable, people need to fix some potential problems.

\section{RESULTS AND DISCUSSION}

By reviewing the development of the auction, the paper finds that the auction has changed from selling people and war trophies to valuable artworks and some small life stuffs. During the process, many different types of auctions occur, including English auction, Dutch auction, first price auction, silent auction, etc. Then, entering the 21 st century, many auctions began to convert to online. As the types of auctions increase, it will be difficult for people to choose a suitable one to cope with the specific situation. To use it in the right way, people have to know different types of auctions' distinctiveness. The Dutch auction is faster, but it applies to some non-durable goods. If the company wants to sell some items quickly to ensure quality, the Dutch auction will be the best choice. English auction is comparatively slower, but sellers can always earn a high profit. It usually applies to some valuable and expensive items since their price is ascending.

In the future, as long as the internet exists or even develops to be more advanced, the future of auctions 
will be inseparable from the website. Holding online auctions will be an inevitable trend. Furthermore, due to some uncontrolled factors like Covid 19, many offline auction companies were closed and ran in the loss. By contrast, the online auction is more stable, and more companies will choose the online auction to earn more profits. After all, the internet has a little probability of being collapsed.

Nevertheless, The Art Newspaper claims that during the Covid 19, live auctions have been pushed back or moved online, but the number of sales slashed. Although sellers could earn money, it was still lower than that of live auctions. It says that more than $\$ 10$ million consignments are as rare as hen's teeth [15]. Thus, the online auction is not mature enough now. There is still a long journey to develop it. Thus, to cope with the trend of the online auction, people have to prepare for it earlier. There are several suggestions. Firstly, for auction companies, their focus should shift from offline auctions to the online application. Thus, they should hire more employees to develop the online auction application to attract people. Besides, they should make some new rules and functions on the auction website to make the auction convenient for people. Secondly, people who want to buy items by auctions but are not adept at online technology should master the use of auction websites as soon as possible.

\section{CONCLUSION}

By reviewing the development of the auction, the paper claims that the auction's form has changed a lot since it was invented. In ancient Greece and Rome, the auction's form was very simple, often used to sell humans like women and slavers. Later, several auction forms were invented corresponding to different needs. To sell famous valuable artworks, people would use English auction.To sell some non-durable items like fish and cut flowers, people used Dutch auction. Entering the 21 st century, many auctions converted to online. However, as there are many types of auctions, using correct and suitable types is also difficult. By comparing the English and Dutch auctions, the article claims the features of these two auctions, which can help people choose an auction to match the certain situation. (see table 1)

Table 1. The comparison between Dutch and English auction

\begin{tabular}{ccc}
\hline & Dutch auction & English auction \\
\hline Process & Descending & Ascending \\
Speed & Quick & Slow \\
Strategies & (a) personal & (a) personal \\
& valuation & valuation \\
& (a) personal & (b) prior \\
\hline
\end{tabular}

\begin{tabular}{|c|c|c|}
\hline & $\begin{array}{l}\text { valuation } \\
\text { (a) personal } \\
\text { valuation }\end{array}$ & $\begin{array}{l}\text { assessment of } \\
\text { rival } \\
\text { (c) new } \\
\text { information } \\
\text { obtained }\end{array}$ \\
\hline Application & $\begin{array}{c}\text { Non-durable } \\
\text { products }\end{array}$ & Valuable artworks \\
\hline
\end{tabular}

Finally, the paper predicts the future of the auction. The internet has been worldwide, and almost everyone uses technical devices. People have been suitable to use things online. Besides, holding auctions online is convenient for people since they don't have to go out; instead, they can just sit at home to finish an auction. Especially when there is a Covid 19, going outside becomes more and more difficult. Then, auctioning online will be important. Currently, there are multiple auction websites provided for people. However, there should be more websites if most of the auctions will be held online in the future so that the website won't be crowded and people's demands can be reached.

As the society develops faster and faster, many things have been changed quickly. This paper predicts the future direction of the auction's development, so people who engage in the auctions can adjust their strategy to adapt the future development easily.

\section{REFERENCES}

[1] Menezes, Flavio M., and Paulo K. Monteiro. "An Introduction to Auction Theory." 2004, doi:10.1093/019927598x.001.0001.

[2] "A Short History of Auctioneering." Gov, www.gov-auctions.org/b/a-short-history-ofauctioneering.

[3] Fluvià, Modest, et al. "Buyer and Seller Behavior in Fish Markets Organized as Dutch Auctions:

Evidence from a Wholesale Fish Market in Southern Europe." Fisheries Research, vol. 127-128, 2012, pp. 18-25., doi:10.1016/j.fishres.2012.04.010.

[4] What's the Future of Auctions? - Ezinearticles. ezinearticles.com/?Whats-the-Future-ofAuctions?\&id=3878079.

[5] Adams, Dave. "Online Auctions: How Internet \& Technology Are Changing Auctions." REALTORS ${ }^{\circledR}$ Land Institute, Dave Adams Https:/Www.rliland.com/WpContent/Uploads/RLI-Logo_Padding.Png, 15 June 2018, www.rliland.com/online-auctions-internettechnology-changing-auctions/. 
[6] Feldman, Robert A., and Rajnish Mehra. "Auctions: Theory and Applications." Staff Papers International Monetary Fund, vol. 40, no. 3, 1993, p. 485., doi:10.2307/3867445.

[7] "Candle Auctions." Oxford Reference, www.oxfordreference.com/view/10.1093/oi/authori ty.20110803095546192.

[8] "Blog Entry." Getting to Know Dutch Auctions Optimal Auctions, www.optimalauctions.com/getting-to-know-dutchauctions.jsp\#: :text=The $\% 20$ history\%20and $\% 20$ or igin $\% 20$ of $\% 20$ the $\% 20$ Dutch $\% 20$ Auction,they $\% 20$ were $\% 20$ considered $\% 20$ the $\% 20$ science $\% 20$ they $\%$ 20 are $\% 20$ today.

[9] "History of Auctions: From Ancient Greece to Online Auctions." Müzayedelerin Tarihi: Antik Yunan'dan Online Müzayedelere | Eker Gallery | Online Müzayede Ve Antika Evi, www.ekergallery.com/en/blog/889/muzayedelerintarihi-antik-yunan-dan-online-muzayedelere.

[10] Milgrom, Paul R., and Robert J. Weber. "A Theory of Auctions and Competitive Bidding."
Econometrica, vol. 50, no. 5, 1982, p. 1089 ., doi:10.2307/1911865.

[11] 1 Revenue EQUIVALENCE Theorem - Chandra Chekuri.

chekuri.cs.illinois.edu/teaching/spring2008/Lecture s/scribed/Notes20.pdf.

[12] Time Is Money: The Effect of Clock Speed On SELLER'S...www.personal.psu.edu/amk17/TimeIs Money_onlineversion.pdf.

[13] Athey, Susan (2001), "Single Crossing Properties and the Existence of Pure Strategy Equilibria in Game of Incomplete Information," Econometrica, 69, 851-890.

[14] Hughes, A. "Retailers, Knowledges and Changing Commodity Networks: The Case of the Cut Flower Trade." The Blackwell Cultural Economy Reader, pp. 210-230., doi:10.1002/9780470774274.ch12.

[15] Adam, Georgina. "Auctions: What Will Change, Post-Covid-19?" The Art Newspaper, The Art Newspaper, 27 Jan. 2021, www.theartnewspaper.com/comment/auctionswhat-will-change-post-covid-19. 